Revue musicale OICRM

\title{
Factors Influencing Technology Use in Aural Skills Lessons
}

\section{Justine Pomerleau Turcotte, Maria Teresa Moreno Sala et Francis Dubé}

Volume 4, numéro 1, 2017

Apprendre et enseigner la musique au XXI ${ }^{\mathrm{e}}$ siècle. Nouvelles propositions pédagogiques

URI : https://id.erudit.org/iderudit/1040297ar

DOI : https://doi.org/10.7202/1040297ar

Aller au sommaire du numéro

\section{Éditeur(s)}

Observatoire interdisciplinaire de création et recherche en musique (OICRM)

ISSN

2368-7061 (numérique)

Découvrir la revue

Citer cet article

Pomerleau Turcotte, J., Moreno Sala, M. T. \& Dubé, F. (2017). Factors Influencing Technology Use in Aural Skills Lessons. Revue musicale OICRM, 4(1), 1-16. https://doi.org/10.7202/1040297ar

\section{Résumé de l'article}

En Amérique du Nord, la formation auditive (FA) est habituellement enseignée aux enfants durant les leçons instrumentales individuelles. La dictée musicale et la lecture à vue chantée peuvent causer des difficultés à certains apprenants, mais l'usage d'outils technologiques appropriés pourrait faciliter le processus. Par contre, l'utilisation des technologies de l'information et des communications (TIC) par les professeurs de musique dans un contexte d'enseignement de la FA n'a pas encore été documentée. Un questionnaire en ligne a été distribué au Québec dans le but de répondre aux questions de recherche suivantes : 1) Dans quelle mesure les professeurs d'instrument utilisent-ils les TIC lorsqu'ils enseignent la FA aux enfants de 6 à 12 ans ? ; 2) Existe-t-il un lien entre la fréquence d'utilisation des TIC par les professeurs et leurs caractéristiques sociodémographiques, leur expérience d'apprentissage de la FA et leur perception de l'enseignement de la FA ? Les résultats suggèrent que l'usage des TIC pour enseigner la FA est peu répandu. De plus, il est négativement corrélé avec l'âge, le sentiment de compétence vécu pendant l'apprentissage ainsi que le sentiment de compétence pour enseigner la FA. Enfin, les professeurs de piano et les femmes ont moins tendance à utiliser les TIC et les utilisent moins souvent. Une meilleure compréhension de la perception que les professeurs ont des technologies sera utile afin de développer des ressources adaptées aux besoins de ces derniers.
Ce document est protégé par la loi sur le droit d'auteur. L'utilisation des services d'Érudit (y compris la reproduction) est assujettie à sa politique d'utilisation que vous pouvez consulter en ligne.

https://apropos.erudit.org/fr/usagers/politique-dutilisation/ 


\title{
Factors Influencing Technology Use in Aural Skills Lessons
}

\author{
Justine Pomerleau Turcotte, \\ Maria Teresa Moreno Sala and Francis Dubé
}

\begin{abstract}
In North America, aural skills (AS) are usually taught to children during the instrumental music lessons. While learning musical dictation and sight-singing can be difficult for some learners, the use of appropriate technological tools could facilitate the process. However, the use of information and communication technologies (ICT) by music teachers in aural skills instruction to children have not been documented. An online survey was conducted in the Province of Quebec (Canada) in order to answer the following questions: 1) To what extent do instrumental music teachers use ICT when teaching As to children between 6 and 12 years old?; 2) Are the teachers' socio-demographic characteristics, As training and perception of AS teaching linked to the use and the frequency of use of Іст? The results show that the use of Іст to teach As is still relatively uncommon. Furthermore, it would be negatively correlated with age, competence felt during training and perceived competence to teach AS. Finally, it appears that a smaller proportion of piano teachers and women use ICT, or use them less often. A better understanding of the teachers' perception of technology could help develop more adapted resources.
\end{abstract}

Keywords: aural skills; computer; ear training; smartphone; technology.

\section{Résumé}

En Amérique du Nord, la formation auditive (FA) est habituellement enseignée aux enfants durant les leçons instrumentales individuelles. La dictée musicale et la lecture à vue chantée peuvent causer des difficultés à certains apprenants, mais l'usage d'outils technologiques appropriés pourrait faciliter le processus. Par contre, l'utilisation des technologies de l'information et des communications (TIC) par les professeurs de musique dans un contexte d'enseignement de la FA n'a pas encore été documentée. Un questionnaire en ligne a été distribué au Québec dans le but de répondre aux questions de recherche suivantes : 1) Dans quelle mesure les professeurs d'instrument utilisent-ils les TIC lorsqu'ils enseignent la FA aux enfants de 6 à 12 ans ?; 2) Existe-t-il un lien entre la fréquence d'utilisation des TIC par les professeurs et leurs caractéristiques sociodémographiques, leur expérience d'apprentissage de la FA et leur perception de l'enseignement de la FA ? Les résultats suggèrent que l'usage des TIC pour enseigner la FA est peu répandu. De plus, il est négativement corrélé avec l'âge, le sentiment de compétence vécu pendant l'apprentissage ainsi que le 
sentiment de compétence pour enseigner la FA. Enfin, les professeurs de piano et les femmes ont moins tendance à utiliser les TIC et les utilisent moins souvent. Une meilleure compréhension de la perception que les professeurs ont des technologies sera utile afin de développer des ressources adaptées aux besoins de ces derniers.

Mots clés : compétences auditives ; formation auditive ; ordinateur ; technologie ; téléphone intelligent.

\section{INTRODUCTION}

Aural skills (AS) are part of the training of most musicians. While some begin their study at college level, many children learn it in one-on-one settings, during their instrumental music lessons. AS is an efficient way to develop musicianship (Karpinski 2000) and is also linked to enhanced results in instrumental performance (Rogers 2013), composition (ibid.), and instrumental sight-reading (Mishra 2014). Unfortunately, those desirous to pursue their musical learning in college often face difficulties that probably come from a lack of precollegial training (Anderman 2011; Hedges 1999; Powell 2013). For example, in Cégep Saint-Laurent, a college in Quebec, 45\% of students enrolled for autumn trimester in 2011, 2012, and 2013 were ranked in the weakest courses in AS, and $24 \%$ of those students considered as weak failed their first semester (Fournier 2015). Consequently, there seems to be a need for a better training for young learners. Perhaps the use of Information and Communication Technologies (ICT) could be a way to better support their learning process.

Data processing devices, such as computers, smartphones and electronic tablets, are ubiquitous in our lives, and therefore have the potential to shape the way music is taught. An inquiry by Pew Research Centre showed that in 2015, 68\% of American adults possessed a smartphone, and that $45 \%$ of them also possessed an electronic tablet (Anderson 2015). The situation is very similar in Quebec, where a survey conducted with 1004 adults revealed that $52 \%$ own a smartphone, and that $39 \%$ of them own a numeric tablet as well; those numbers are even higher for $\mathrm{X}$ generation members, as $63 \%$ of them own a smartphone, and $45 \%$ of them own an electronic tablet (CEFRIO 2015). Therefore, one can assume that many music teachers are using ICT in their daily life, and can also use them in their studio music lessons.

In schools, ICT, such as electronic tablets, can serve many purposes, such as helping children with special needs (Maich and Hall 2016), facilitating the learning of mathematics for children in preschool (Kosko and Ferdig 2016) or improving reading achievement of teenagers (Biggs et al. 2008). Likewise, ICT are mainstream in music classrooms as they can be used for composition (Bolton 2008; Hickey 1997; Kim 2013; Seddon and O'Neill 2003; Shibazaki and Marshall 2013; Ward 2009), performance (Silveira and Gavin 2016), listening (Stowell and Dixon 2014), and notation (Dunbar 2015).

ICT are also relevant for instrumental music lessons; for example, they can be used to help the pianists to improvise (Rowe, Triantafyllaki and Anagnostopoulou 2015), to create a web portfolio (Brook and Upitis 2015) or to reach aural skills examination requirements (Chen 2015). Nonetheless, studio teachers are divided concerning the use of technological tools. According to a survey completed by 1468 music teachers 
in Canada (Upitis et al. 2016), 63\% of them never integrate the use of a computer in their lessons. Some of them use their own devices to teach, such as electronic tablets (24\%), iPods $(12 \%)$, or smartphones (24\%). They mostly use them to record their students and to show models of relevant performances. Furthermore, $68 \%$ believe that technologies can improve learning, 61\% consider that they can enhance students' motivation, but 33\% think that using technologies require too much time and effort.

Views also differ regarding the use of videogames to improve musical achievement. Some teachers argue that young musicians playing musical videogames, such as Guitar Hero, cannot transfer what they learn to a conventional musical notation, while others believe that these applications can improve eye-hand coordination (Gower and McDowall 2012). Nonetheless, playing rhythmic videogames could be associated with the development of traditional musical abilities. Peppler, Downton and Hay (2011) recruited 26 children, of which 19 were involved in a Rock Band after-school club. They observed a positive correlation between the number of sessions realized and their performance in traditional rhythmic tasks (transcription, echoes and sight-reading). This means that a scrolling, unconventional musical notation could help develop musical understanding. Also, karaoke games, as they provide a visual feedback, might improve singing achievement. A study conducted by Paney (2015) with 28 non-musician undergraduates suggests that a 10-minute session of the game Karaoke Revolution Presents. American Idol Encore had a positive impact on pitch-matching. The task was the same for the pretest and post-test, namely singing "Happy Birthday to You" over a recording with a flute playing the melody and a piano playing simple chords. Mean scores, which were established based on the deviation from the target note, significantly improved after treatment, while the number of wrong pitches significantly dropped.

Visual feedback provided by a technological tool could also benefit younger music learners. The efficiency of the computer game Singing Coach was tested among 30 teachers and their 2021 third-grade students (Paney and Kay 2015). Their ability to sing the song "America" was tested in the fall session and again in the following spring session. The percentage of right pitches and rhythms was calculated for each participant. Significantly higher results were obtained for children who played with the software between one and five times during the course of the study, and the improvement was greater for boys than girls. On the other hand, a study of sixth-grade children engaged in a choir showed no significant improvement in sight-reading between participants who used the software SmartMusic and their peers who did not (Petty and Henry 2014). Further studies would therefore be needed to assess the impact of ICT on sight-reading capacities. In summary, technology can, mostly due to the visual feedback it allows, assist in the development of singing ability, which is traditionally required in aural skills lessons (Hoppe, Sadakata and Desain 2006; Leong and Cheng 2014; Paney 2015; Paney and Kay 2015; Welch et al. 2005; Welch, Howard and Rush 1989).

Ear-training software has been a subject of great interest for many decades (Allvin 1971; Canelos et al. 1980; Hess 1994; Hofstetter 1980; Karahan 2014; Peters 1993), but very few studies target young learners. Paule-Ruiz et al. (2016) conducted a pilot study with 43 five-year-old children in order to check if a mobile 
device could assist in auditory discrimination, and to explore the impact of technology on music education for preschool children. The software they used, SAMI, was inspired by the Montessori method and therefore use the same note-colour combinations associated with Montessori bells. This tool is designed to help children develop their ability in pitch identification. The first game, which was the one used for comparison between groups in this study, requires children to listen to the mascot playing a note, and to move a cursor on the computer application to produce an identical sound. After a five-week training, the experimental group used SAMI while the control group did pitch association activities with Montessori bells, and performance of both was compared. For an equivalent pitch association task, children in the experimental group tended to get the right answer in fewer attempts. Interviews also revealed they liked using the device. Finally, the application Auralbook was used by Chen (2015) to investigate the possibility of using mobile learning for aural skills acquisition. He compared the mean scores of frequent users of this application at the beginning and at the end of a six-month period. The biggest improvements were observed in clapping and features identification activities (for example, dynamics and articulation).

Instrumental music teachers working with children between 6 and 12 years old could also benefit from the use of ICT when teaching aural skills, since technology can support singing achievement (Paney 2015; Paney and Kay 2015; Welch et al. 2005) and perception skills (Chen 2015; Paule-Ruiz et al. 2016). Nevertheless, although many adults own data processing devices (Anderson 2015; CEFRIO 2015), few music teachers use them in studios (Dubé, Héroux and Robidas 2016a; Upitis et al. 2016). This paper aims to answer the following research questions:

1. To what extent do instrumental music teachers use ICT when teaching aural skills (AS) to 6 to 12 years old children in the Province of Quebec?

2. Which other factors, such as sociodemographic characteristics, perception of AS learning and perception of As teaching, are related to the use, and frequency of use, of ICT when teaching aural skills?

\section{Methodology}

To answer these research questions, an online questionnaire using LimeSurvey was sent to 871 independent music teachers working in the Province of Quebec selected from a database provided by the Centre d'excellence en pédagogie musicale of the Faculty of Music of Université Laval. This database included teachers from diverse regions of the province and various affiliations to examination boards (including École préparatoire de musique Anna-Marie-Globenski of Université Laval, École de musique Vincent-d'Indy and École préparatoire de musique of UQÀM [Université du Québec à Montréal]). Many teachers were not affiliated to any board. The questionnaire was written in French, but the questions have been translated for this paper. It was also shared through social media, and a reminder was sent after two weeks. 159 questionnaires were completed, but 12 were rejected as they did not meet the inclusion criteria (the respondents either were not teaching music in Quebec when the survey was conducted or were not currently teaching to the target age group). Before the questionnaire was sent, it was tested in a pilot conducted with three 
teachers from different backgrounds to be certain that the terms used were understandable no matter the instrument taught or the musical style. Some questions have been reformulated for more clarity. The final survey has been approved by the Universite Laval ethical committee (CÉRUL: 2015-156 A-1/13-10-2015). The questionnaire could be completed in about 20 minutes, depending on the answers given. This paper focuses on the answers given to the following categories of questions:

Profile

We first wanted to gather information on the sociodemographic characteristics of our respondents. Therefore, we asked them their age, gender, the instruments they taught, the last diploma they obtained, and their affiliation, if applicable, to an examination board. We wanted to verify if those factors could have an impact on the way teachers use ICT.

Use of Technology in AS Lessons

In order to study the extent to which instrumental music teachers use ICT for As teaching, we asked them to rate, on a five-points scale, their frequency of using computers, electronic tablets and mobile phones. They were also asked about how often they used software and applications. They could choose between the following answers: a) never; b) sometimes; c) often; d) very often; e) every lesson.

\section{Factors Related to the Use of Technology in AS Lessons}

We also wanted to verify if other factors were related to the use, and frequency of use, of ICT in As teaching contexts. We consequently focused on three broad characteristics for our respondents: their experience with As learning, their perception of As teaching, and their appreciation of available resources to teach As. These factors were assessed on five-point scales, and to determine their level of agreement with statements designed to reflect their perceptions, participants had to choose between the following answers: a) totally disagree; b) disagree; c) neither disagree nor agree; d) agree. The statements related to the perception of As learning were: a) when I was learning As, I was feeling competent; b) I liked to learn As; c) when learning As, I was experiencing anxiety; d) As was useful to my musical learning; e) today, I still use the skills developed in As classes. The statements conceived to measure the perception of As teaching were the following: a) I like to teach As; b) I find As difficult to teach; c) I think As is useful for my students; d) I feel competent to teach As. Finally, the last questions concerned the respondents knowledge of available resources to teach As: a) I think there is a sufficient number of pedagogical resources to teach As; b) I think the resources available to teach As are of good quality; c) I think the examination board program I am following is relevant; d) I think the resources provided by the examination board are of good quality. The type of resource was not specified in the questionnaire, so teachers could provide answers taking into account textbooks, apps, software, etc. Questions regarding the perception of As teaching and available resources were followed by an open-ended question, "Why?" 
Only the answers of respondents who reported including As in their lessons were considered $(n=124)$. Chi-square tests were conducted in order to establish relations between factors linked to the use of technologies, and use frequency of ICT when teaching aural skills. Cramer's V test was used to determine the strength of the relationship. In some situations, the Cochran-Mantel-Haenszel (CMH) test was chosen over chi-square when it could lead to a better understanding of linear associations, as it considered the ranking between modalities. In those cases, this kind of analysis is more powerful than chi-square and Cramer's V tests. Multivariate analysis was not used because the sample did not meet two of the required assumptions, namely the normality of the distribution and the homogeneity of variance (Glass and Hopkins [1970]1995).

RESULTS

Sample Description

Considering the age of respondents, $61.3 \%$ were aged 40 or less, while $38.7 \%$ were aged 41 or older. The youngest participant was 15 years old, and the oldest, 77 years old. The most notable feature is that the sample was mainly made up of women $(88.4 \%)$, and men were underrepresented (11.6\%). Also of importance, the vast majority of participants taught piano (72.5\%). Finally, $84.2 \%$ of teachers who included AS in their lessons had a college degree, whether a bachelor's degree $(42.5 \%)$ or a master's degree (41.7\%). The remaining participants $(15.8 \%)$ had a pre-college diploma.

Concerning As teaching habits, most respondents taught As on a regular basis. Indeed, $55.7 \%$ taught it at least once a week, $36.1 \%$ two or three times a month, $5.7 \%$ once a month and $2.5 \%$ teach less than once a month. Moreover, some teachers did not teach As to all of their students; in fact, $46.8 \%$ taught it to $75 \%$ of their students or less.

\section{Use of Technology in AS Lessons}

Taking into account every respondent who reported using at least one technological device sometimes, often, very often or in every lesson, $47.5 \%$ of our respondents reported using ICT when teaching As with at least one device. However, when devices are considered individually, their use rate remains very low, and each of them is never used by about three-quarter of participants. A more detailed description of technology use is presented in Figure 1. 


\begin{tabular}{|c|c|c|c|c|c|}
\hline & Never & Sometimes & Often & Very often & Every lesson \\
\hline Computer & $78.6 \%$ & $13.7 \%$ & $4.3 \%$ & $1.7 \%$ & $1.7 \%$ \\
\hline $\begin{array}{c}\text { Electronic } \\
\text { tablet }\end{array}$ & $76.5 \%$ & $13.0 \%$ & $4.3 \%$ & $6.1 \%$ & $0.0 \%$ \\
\hline $\begin{array}{c}\text { Mobile phone } \\
\text { T. }\end{array}$ & $75.7 \%$ & $15.7 \%$ & $4.3 \%$ & $3.5 \%$ & $0.9 \%$ \\
\hline
\end{tabular}

Figure 1: Frequency of use of some technological devices.

The use of software and applications, independently of the device, has also been investigated. Software is never used by a vast majority of our respondents, and nobody uses it in every lesson. A few participants gave examples of software used. One of them reported using the website Metronimo to work on note reading. iReal Pro, a software providing audio accompaniments, was mentioned once, like Garage Band, a recording software included on Apple devices. Two notation software were mentioned, each one by two participants (Encore and Finale). One teacher reported using a transcription facilitator, which is a software that allows to slow the recording for transcription purposes (Transcribe). Finally, only one ear-training software was mentioned (EarMaster) by one participant. Also, most respondents never used applications, and none used applications in every lesson. Some of the applications mentioned are tools that do not require the use of technologies; four teachers reported using metronome apps and two teachers said they use tuner applications. Notes reading apps were common, including Note Trainer, Learn Notes, or Note Challenge. A few examples of apps specifically designed for AS were listed, such as Blob Chorus, Good Ear, and Interval Ear Trainer. The frequency of use of software and applications is presented in Figure 2.

\begin{tabular}{|c|c|c|c|c|c|}
\hline & Never & Sometimes & Often & Very often & Every lesson \\
\hline Software & $92.7 \%$ & $3.6 \%$ & $1.8 \%$ & $1.8 \%$ & $0.0 \%$ \\
\hline Applications & $82.5 \%$ & $12.3 \%$ & $2.6 \%$ & $2.6 \%$ & $0.0 \%$ \\
\hline
\end{tabular}

Figure 2: Frequency of use of software and applications.

Factors Related to the Use of Technologies

1. Age

Age is significantly related to the use of mobile phones when teaching As $\left(\chi_{1 \mathrm{df}}^{2}=4.439, \mathrm{p}=0.044\right)$. Younger teachers showed a higher tendency to use mobile phones, but the link is weak $(\mathrm{V}=0.196)$, and could be explained by the fact that very few teachers use a mobile phone. 


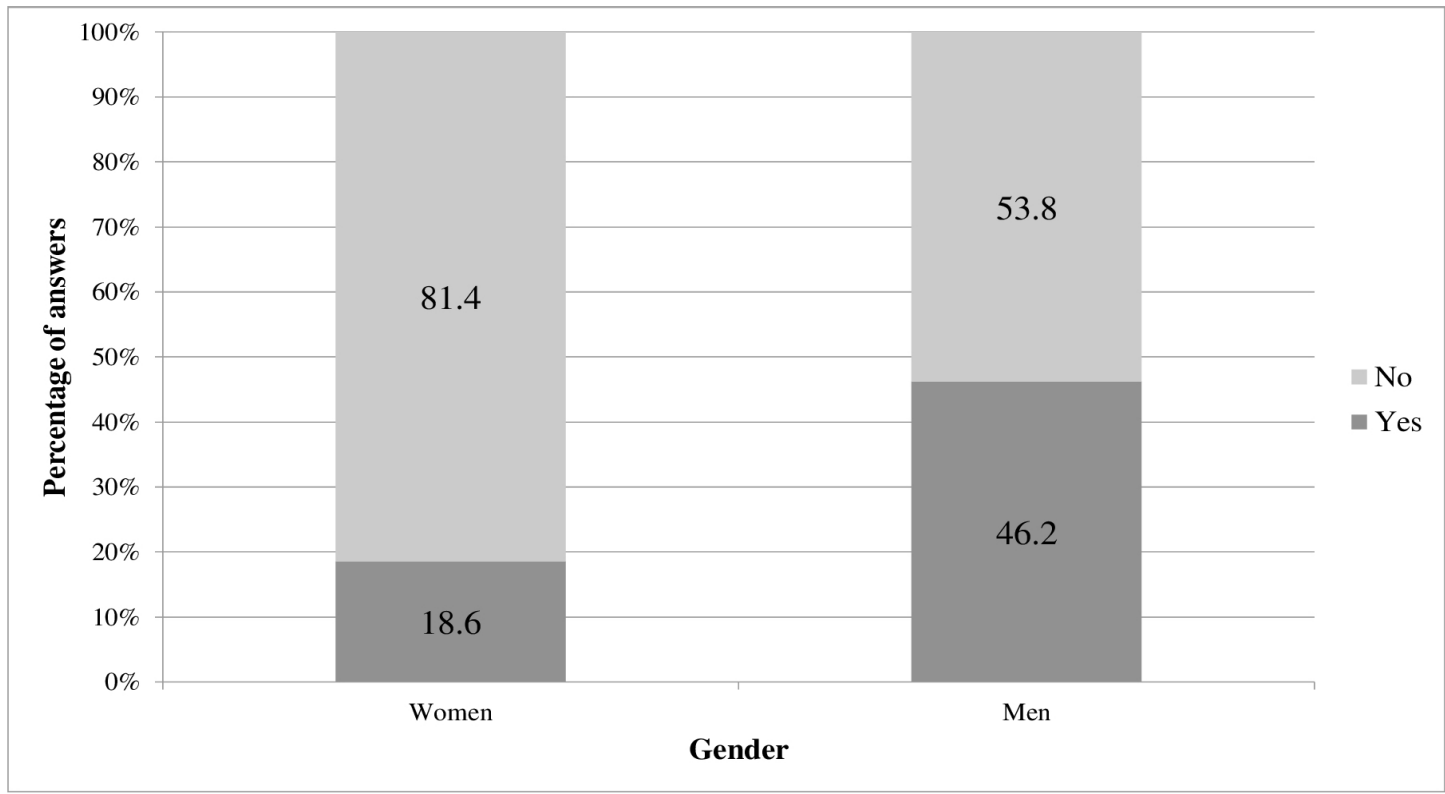

Figure 3: Proportion of men and women using computers when teaching AS.

\section{Gender}

Fisher's exact test revealed that the use of computers is strongly related to gender $(p=0.034)$, as shown in Figure 3. A bigger proportion of men used computers when teaching As. Men also tended to use this tool significantly more often than women $\left(\chi_{1 \mathrm{df}}^{2}=10.720, p=0.046\right)$. The gender difference seems even more noticeable when comparing teachers who never used computers; indeed, $92.2 \%$ of teachers who reported never using computers were women. This link is strong $(\mathrm{V}=0.305)$. Furthermore, the results show that men used mobile phones much more often $\left(\chi_{\text {MHIdf }}^{2}=6.431, p=0.019\right)$. Finally, they reported using software more frequently, which is consistent with our data on computer use $\left(\chi_{3 \mathrm{df}}^{2}=15.916, p=0.017\right)$. This is a strong relationship $(\mathrm{V}=0.384)$. The largest differences are shown between teachers who said they use software very often or never use them: no woman reported using software very often, and $90.0 \%$ of respondents who said they never use software are women.

\section{Instrument}

Some technological tools are used less by pianists than by their non-pianist counterparts. Indeed, a smaller proportion of piano teachers used electronic tablets in their lessons: only $18.3 \%$ used them, compared to $41.4 \%$ of those who teach another instrument $\left(\chi_{1 \mathrm{df}}^{2}=6.203, p=0.022\right)$. This link is moderate $(\mathrm{V}=0.236)$. Also, fewer piano teachers used mobile phones than respondents teaching another instrument: $17.1 \%$ used phones, compared to $44.8 \%$ of participants who do not teach piano $\left(\chi_{1 \mathrm{df}}^{2}=8.965\right.$, $p=0.005)$. This relation is moderately strong $(\mathrm{V}=0.284)$. The instrument taught is also related to the frequency of use of technological tools. Piano teachers tended to use electronic tablets less frequently than other teachers $\left(\chi_{3 \mathrm{df}}^{2}=10.546, p=0.012\right)$, and this link is strong $(\mathrm{V}=0.308)$. Piano teachers also used mobile phones less often $\left(\chi_{4 \mathrm{df}}^{2}=13.264, p=0.007\right)$, and this relation is strong as well $(\mathrm{V}=0.346)$. Both results are 
consistent with the frequency of use of applications by pianists, which is significantly lower than for their non-pianist counterparts $\left(\chi_{3 \mathrm{df}}^{2}=10.343, p=0.026\right)$, with a strong relation $(\mathrm{V}=0.307)$. No piano teacher reported using applications often.

\section{Previous Experience With AS Learning}

When asked to rate the statement "When I was learning As, I was feeling competent," a majority of respondents (63.8\%) said they agreed or totally agreed with this assertion, while $17.2 \%$ of respondents totally disagreed or disagreed, and $19.0 \%$ neither disagreed nor agreed. However, interesting results emerged when we investigated the relationship between the feeling of competence of participants during As learning and their use of technologies when teaching. Indeed, teachers who did not feel competent during their own learning of As showed a higher tendency to use computers when teaching $\left(\chi_{2 \mathrm{df}}^{2}=6.628, p=0.039\right)$, and this relation is moderate $(\mathrm{V}=0.247) .40 \%$ of those who did not feel competent used computers, but this is the case for only $9.5 \%$ of teachers who reported being neutral toward their competence while learning As, and for $17.6 \%$ who were feeling competent. The most noticeable differences in use of ICT emerged between respondents who were not feeling competent during their training and those who were neutral toward their feeling of competence during training or were feeling competent. Figure 4 shows the proportion of computer users for, respectively, respondents who did not feel competent when learning As, those who neither disagree nor disagree with the statement, and those who felt competent. Concerning the statement "As was useful to my musical learning", teachers who did not consider useful what they learned in As classes had a stronger tendency to use computers $\left(\chi_{2 \mathrm{df}}^{2}=8.856, p=0.028\right)$. This relation is moderately strong $(\mathrm{V}=0.284)$. No other significant result was found concerning perception of previous experience with As training.

\section{Perception of Their AS Teaching}

When asked to rate the statement "I feel competent to teach As," a majority (83.2\%) said they agreed, $16.0 \%$ said they neither disagreed nor agreed and $0.8 \%$ of respondents indicated they disagreed (nobody answered "Totally disagree" to this question). Interestingly, when comparing the perceived competence of participants when teaching As and using technologies, we found that teachers who felt competent teaching As used mobile phones to a lesser extent in their teaching compared to teachers who did not feel competent $\left(\chi_{2 \mathrm{df}}^{2}=6.553, p=0.036\right)$. This relation is moderate $(\mathrm{V}=0.242)$. In fact, $100 \%$ of our respondents who did not feel competent used such a device to assist in their teaching, as shown in Figure 5. This figure compares the use of mobile phones by, respectively, teachers who did not feel competent teaching As, teachers who neither disagreed nor agreed with the statement, and teachers who felt competent teaching As. Those who felt competent also tended to use mobile phones less often than the others $\left(\chi_{8 \mathrm{df}}^{2}=30.714, p=0.034\right)$. This relation is very strong $(\mathrm{V}=0.370)$ and is mostly explained by the answers of teachers who did not feel competent to teach As. Furthermore, teachers who did not feel competent tended to use applications more often $\left(\chi_{6 \mathrm{df}}^{2}=36.848\right)$ and this relation almost reaches significance $(p=0.052)$. 
The relation is very strong $(\mathrm{V}=0.409)$. No other significant result was found concerning perceptions of As teaching.

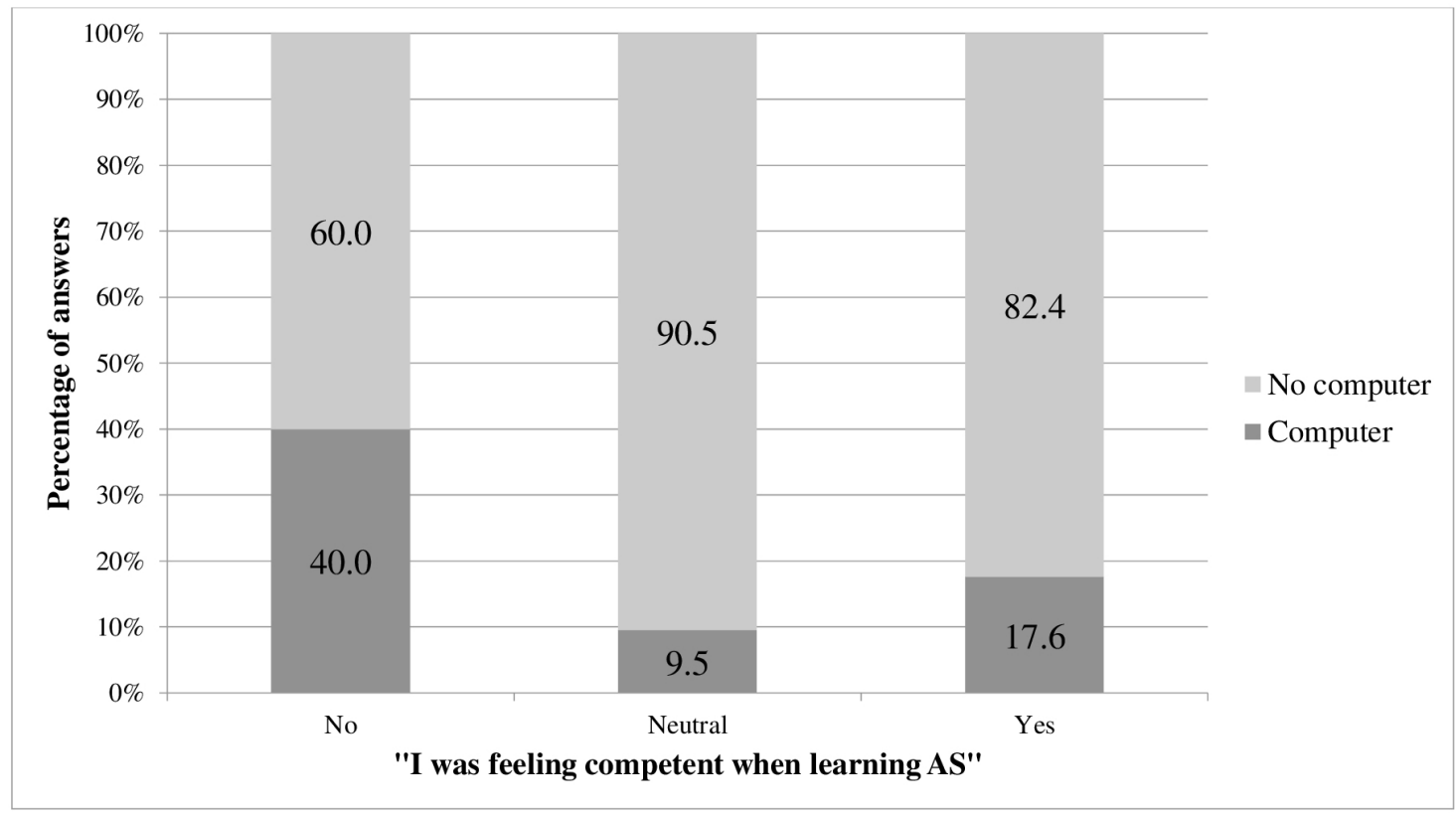

Figure 4: Proportion of teachers using computers, depending on their feeling of competence during training.

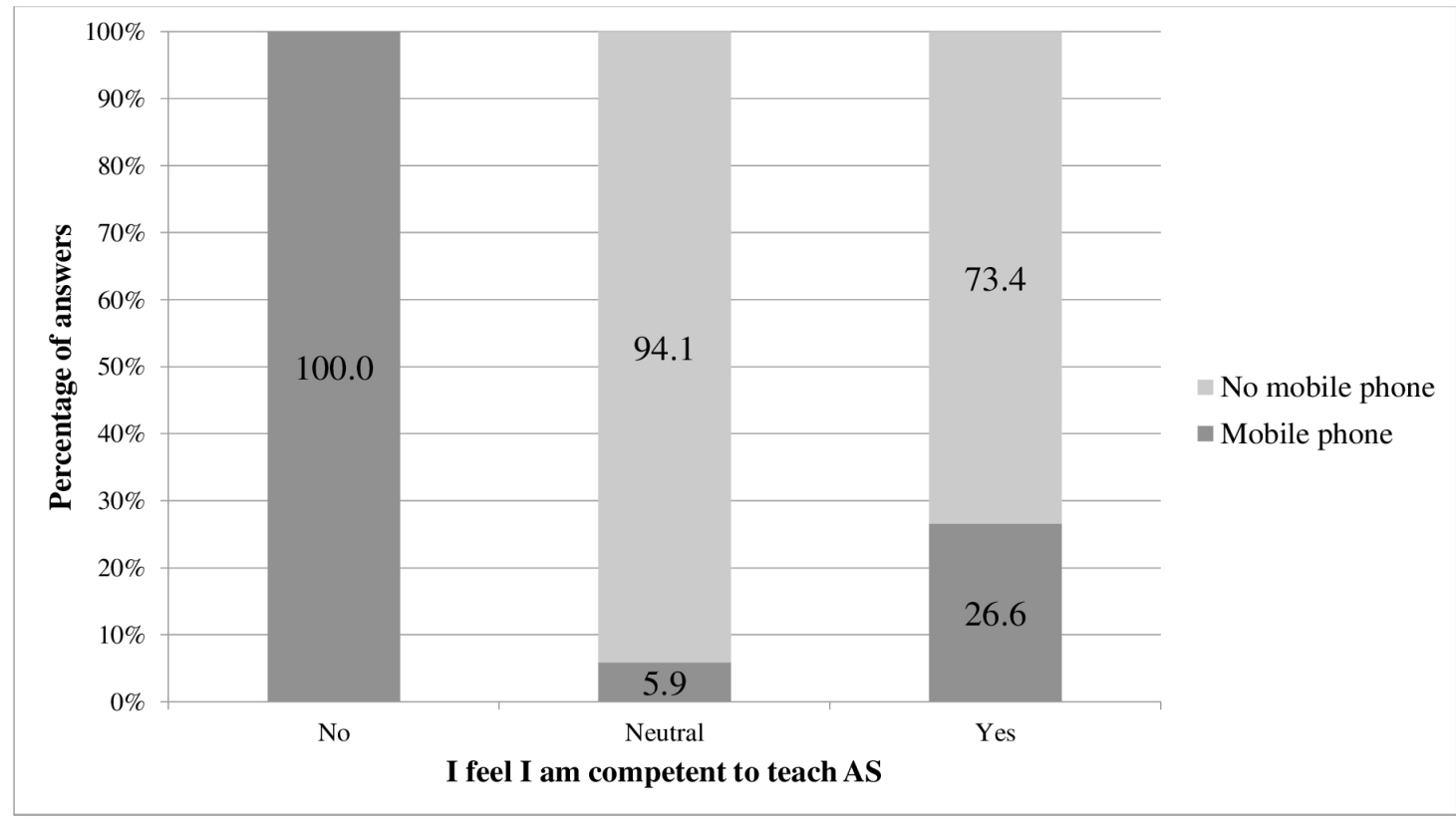

Figure 5: Proportion of teachers using mobile phones, depending on their feeling of competence to teach AS.

\section{Appreciation of Available Resources}

All participants did not share similar views regarding the quantity and quality of resources available to help them teach As. They do not agree either about the relevance of programs offered by the examination boards they are affiliated to. First, when asked to rate the statement: "I think there is a sufficient amount of resources 
available to teach As," $40.0 \%$ of respondents agreed, while $33.6 \%$ neither disagreed nor agreed and $26.4 \%$ disagreed. Teachers who viewed positively the quantity of available resources had a lower rate of use of technological tools (all devices, software and applications included) than those who held a negative view $\left(\chi_{\mathrm{MH} 2 \mathrm{df}}^{2}=4.383, p=0.043\right)$. This result is mostly due to teachers who held a positive view of available resources to help them teach As. Figure 6 compares the use of ICT by teachers who thought there are not enough resources to teach As, those who were neutral and those who thought there are enough resources. Also, a smaller proportion of teachers who considered there are enough resources used mobile phones $\left(\chi_{2 \mathrm{df}}^{2}=9.130, p=0.010\right)$, and this link is moderately strong $(\mathrm{V}=0.296)$.

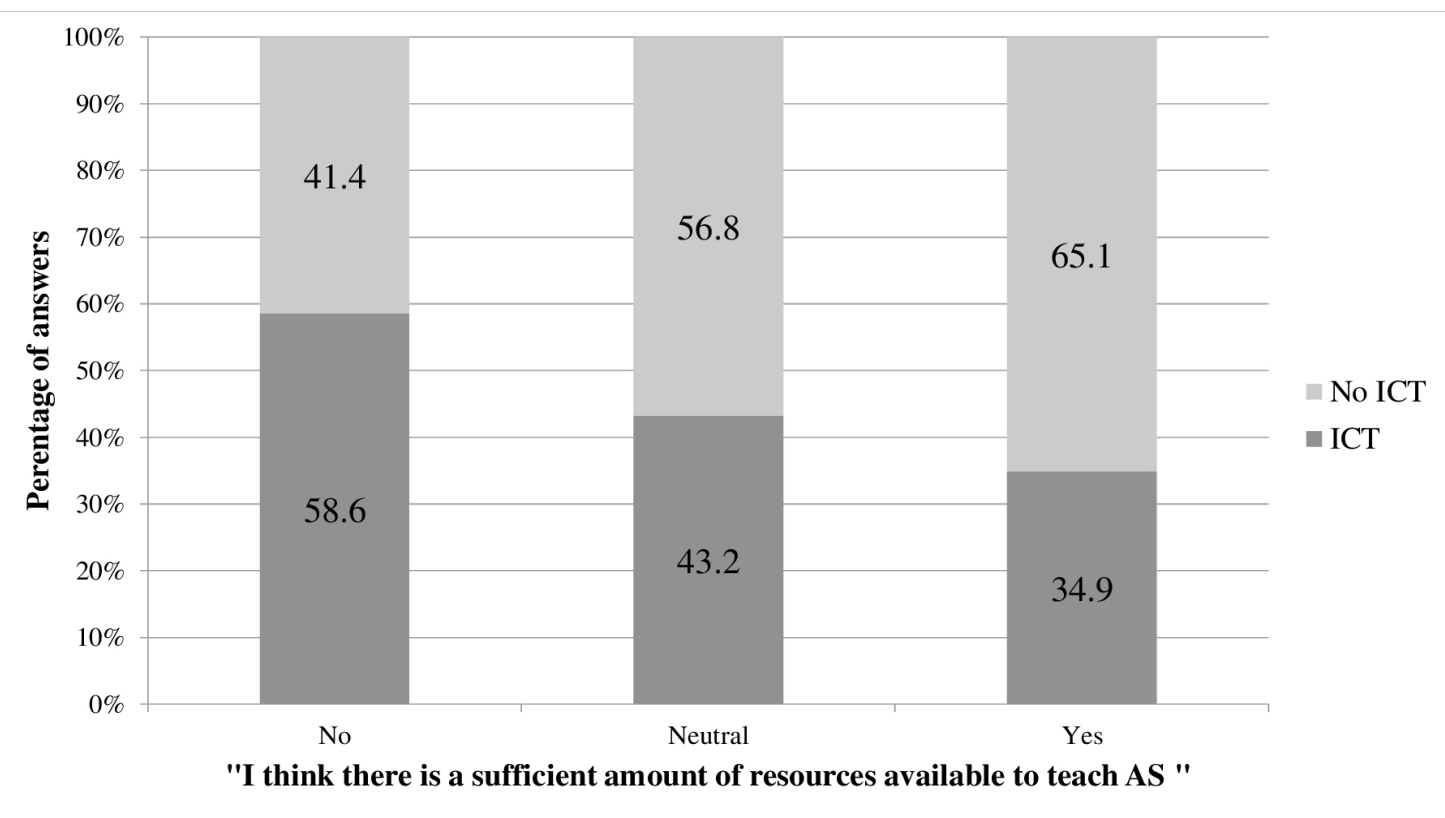

Figure 6: Proportion of teachers using technological tools, depending on their perception of the quantity of available resources.

When asked to rate the statement "I think the resources available to teach AS are of good quality," a majority (52.0\%) agreed, while $30.4 \%$ neither disagreed nor agreed, and $17.6 \%$ disagreed. The latter were more inclined to use electronic tablets than teachers who were satisfied with the quality of resources $\left(\chi_{2 \mathrm{df}}^{2}=8.335, p=0.014\right)$, and this relation is moderately strong $(\mathrm{V}=0.293)$. This means that more teachers not satisfied by the quality of resources used electronic tablets. They also used this device significantly more often $\left(\chi_{6 \mathrm{df}}^{2}=16.053, p=0.013\right)$, and this relation is moderately strong $(\mathrm{V}=0.288)$, meaning that electronic tablet users who were not satisfied by the quality of available resources used this device more often than the others.

Finally, when asked to rate the statement "I think the program of the exam board I am affiliated to is relevant," a majority (60.9\%) agreed or totally agreed, while $18.8 \%$ neither disagreed nor agreed and $20.3 \%$ of the respondents totally disagreed or agreed. The latter tended to use electronic tablets to a lesser extent $\left(\chi_{\text {MH1df }}^{2}=4.161, p=0.039\right)$.

In summary, the results show that the use of ICT to teach As appears to be relatively uncommon. Furthermore, in this sample, younger respondents, teachers who did 
not feel competent when they learned As and teachers who did not feel competent teaching As are those who used ICT the most. Also, teachers who were satisfied with available resources were less prone to use technologies. Finally, piano teachers and women appeared to be using ICT in a smaller proportion, or to use them less frequently.

\section{DiscUSSION}

The results gathered from this survey give an interesting first picture of the perception of technologies used to teach As and of factors related to their use, even if the sample, due to its size and to the fact it is not random, does not allow generalizations. As other studies interested in teachers' use of technologies (Dubé, Héroux and Robidas 2016a; Upitis et al. 2016) confirmed, the use of technologies is not widespread among instrumental music teachers. Specifically, they are not used a lot for As teaching. Interestingly, teachers make less use of software (92.7\%) than computers (78.6\%). The way the latter are used would therefore require further investigation. Also, we do not know to what extent computers and software are used during preparation of lessons, but we can assume that this is the case for notation software. Also of note, the use rates of the different devices (computers, electronic tablets and mobile phones) are about the same. Consequently, we can assume that the utilization of ICT is not influenced by the device type.

Our sample included a very high proportion of women (88.4\%). However, this is often the case when studying the population of studio music teachers; in a study by Upitis et al. (2016), the sample included a majority (88\%) of women, and Uszler (1996) described their sample as almost totally composed of women instrumental teachers. In their study conducted with instrumental musical teachers in Quebec, Dubé, Héroux and Robidas (2016a, b) also obtained a similar proportion, where $80.8 \%$ of their sample were women. Although not surprising, it probably influenced our results greatly, and despite the fact that men were largely underrepresented in our study, our results tend to show important discrepancies in ICT use between men and women.

Moreover, the fact that our sample was not randomized and mostly consisted of piano teachers probably had an influence on the responses. Depending on the instrument played, or taught, different music teaching cultures coexist; for example, pianists tend to focus more on performance, while guitarists tend to focus more on creation, and autonomy (MacIntyre and Potter 2014). Also, the results would have shown more significant gender differences had there been more men in our sample; nevertheless, our sample did not differ in this way from other studies about the same population (Dubé, Héroux and Robidas 2016a; Upitis et al. 2016; Uszler 1996). But even with a small proportion of men, we obtained interesting results that suggest that men use technologies more than women when they teach AS. This is consistent with the findings of Dubé, Héroux and Robidas (2016b), who also observed that men tended to use ICT more often in their instrumental lessons. Our large proportion of piano teachers might be explained by the structure of the database we used to recruit our participants; indeed, it included many teachers affiliated to examination boards, and exams are taken more frequently by piano students; for example, 
in $2016,72.76 \%$ of instrumentalists who went through the annual evaluations of the École préparatoire de musique Anna-Marie-Globenski were pianists (data obtained directly from the institution).

It is also noteworthy that most of the teachers in the sample feel competent to teach As. People already interested in aural skills teaching might have had a greater tendency to fill out the questionnaire. Those who feel less competent have a stronger tendency to use ICT, which can be explained by an exacerbated need to seek for new approaches in order to facilitate their teaching. This could be an advantage for them or their students. On the contrary, teachers who feel competent could rely more on the approaches that they have always used, or that worked well for them, despite the fact that their students could have different needs. It would also be interesting to see if the proportion of teachers who feel competent would have been the same with the use of a sample including more teachers teaching instruments other than piano. Likewise, feeling competent to teach As does not mean that no challenge is faced. We need a more complete view of the difficulties faced by the teachers, and the strategies they use to overcome them; the answers might perhaps imply the use of technologies. Furthermore, it is interesting to see that teachers who are more critical towards available resources have a stronger tendency to use technological tools. This suggests that dissatisfaction can lead teachers to search more resources, including digital ones.

The fact that some teachers feel they use technology in their lessons because they use the metronome on their smartphones suggests that they might not use ICT to a full extent. As a matter of fact, it could be useful in future studies to write the questions regarding technology use differently, to separate technology-dependent tools from others that can exist in a non-electronic form, like a metronome, a tuner or a recorder. This is what Upitis et al. (2016) did in their survey on independent music teachers; questions about the use of digital recorders (used by $62 \%$ of respondents) and the use of a metronome, either analogic or digital (used by $99 \%$ of respondents) were dealt with separately. Recorders and metronomes were the most used technological tools in their study.

\section{CONCLUSION}

The most important findings in this study are, first, that the use of ICT to teach As is not widespread, and, second, that various factors are linked to their use. Indeed, characteristics such as age, gender, instrument taught, competence felt during As training, competence felt when teaching as and perception of available resources are linked to the use of technological tools.

Because teachers who use ICT on a regular basis are not common, at least in this sample, conducting a case study with a few teachers sharing this characteristic would be of great interest, as it would give insights about reasons to use technology and ways to use them efficiently. It would also be interesting to investigate why some teachers are so reluctant to use Iст; the price of the devices, or the feeling that technology does not belong to the music studio, could be plausible explanations. Moreover, it is also possible that teachers are not aware of existing resources, or don't have time to search 
for additional resources.

There are also relatively few software and applications available in French; this could explain why they are rarely used by teachers in Quebec, who mostly teach in this language. Further investigation would be needed to have a better understanding of teachers' needs in aural skills resources, and to build the basis necessary for development of better material and better dissemination of resources.

FUNDING

This work was supported by a grant from the Social Sciences and Humanities Research Council (sSHRc), from the Joseph-Armand Bombardier Canada Graduate Scholarships Program.

\section{ACKNOWLEDGMENTS}

The authors would like to thank Manon Saint-Pierre for the linguistic revision.

\section{BIBLIOGRAPHY}

Allvin, Raynold L. (1971), "Computer-Assisted Music Instruction. A Look at the Potential," Journal of Research in Music Education, vol. 19, n 2, p. 131-143.

Anderman, Mark A. (2011), "Musicianship Instruction in California Community Colleges," Doctoral thesis, Boston University.

Anderson, Monica (2015), Technology Device Ownership. 2015, http://www.pewinternet. org/2015/10/29/technology-device-ownership-2015, accessed August 19, 2016.

Biggs, Marie C., et al. (2008), "Using an Interactive Singing Software Program. A Comparative Study of Struggling Middle School Readers," Reading Psychology, vol. 29, n 3, p. 195-213.

Bolton, Jan (2008), “Technologically Mediated Composition Learning. Josh’s Story”, British Journal of Music Education, vol. 25, n 1, p. 41-55.

Brook, Julia, and Rena Upitis (2015), "Can an Online Tool Support Contemporary Independent Music Teaching and Learning?," Music Education Research, vol. 17, n 1, p. 34-47.

Canelos, James J., et al. (1980), "Evaluation of Three Types of Instructional Strategy for Learner Acquisition of Intervals," Journal of Research in Music Education, vol. 28, n 4, p. 243-249.

CEFrio (2015), NETendances, http://www.cefrio.qc.ca/media/uploader/35 54 .pdf, accessed August 18, 2016.

Chen, Chi Wai Jason (2015), "Mobile Learning. Using Application Auralbook to Learn Aural Skills," International Journal of Music Education, vol. 33, nº 2, p. 244-259.

Dubé, Francis, Héroux, Isabelle, and Noémie Robidas (2016a), "Factors Influencing Instrumental Music Teachers' Use of Music Technologies with Young Students," Poster presented at the International Society of Music Education World Conference, Glasgow.

Dubé, Francis, Héroux, Isabelle, and Noémie Robidas (2016b), "Recherche sur l'utilisation des technologies par les professeurs d'instrument au Québec," Communication at the Journées internationales de recherche et de pratique en pédagogie instrumentale et vocale, Aix-en-Provence.

Dunbar, Laura (2015), "Free Notation Apps. What is Out There?," General Music Today, vol. 29, n 2, p. 39-44. 
Fournier, Guillaume (2015), "Recension, description et catégorisation des stratégies cognitives liées à la lecture à vue chantée et à l'apprentissage du solfège chez les étudiants en musique de niveau collégial," Master Thesis, Université Laval.

Glass, Gene V., and Kenneth D. Hopkins ([1970]1995), Statistical Methods in Education and Psychology, Boston, Pearson.

Gower, Lily, and Janet McDowall (2012), "Interactive Music Video Games and Children's Musical Development", British Journal of Music Education, vol. 29, nº 1, p. 91-105.

Hedges, Don P. (1999), "Taking Notes. The History, Practice, and Innovation of Musical Dictation in English and American Aural Skills Pedagogy," Doctoral Thesis, Ann Arbor.

Hess, George J. (1994), "Dictation Tutor. The Effectiveness of a Curriculum-Specific Tutorial in the Acquisition of Aural Discrimination Skills at the College Level," Doctoral Thesis, Ann Arbor.

Hickey, Maud (1997), "The Computer as a Tool in Creative Music Making," Research Studies in Music Education, vol. 8, n 1, p. 56-70.

Hofstetter, Fred T. (1980), "Computer-Based Recognition of Perceptual Patterns in Chord Quality Dictation Exercises," Journal of Research in Music Education, vol. 28, n 2, p. 83-91.

Hoppe, Dave, Makiko Sadakata, and Peter Desain (2006), "Development of Real-Time Visual Feedback Assistance in Singing Training. A Review," Journal of Computer Assisted Learning, vol. 22, $\mathrm{n}^{\mathrm{o}} 4$, p. 308-316.

Karahan, Ahmet Suat (2014), "The Evaluation of Synchronous Distance Ear Training Compared to the Traditional Ear Training," Educational Research and Reviews, vol. 9, n 23, p. 1266-1274.

Karpinski, Gary S. (2000), Aural Skills Acquisition. The Development of Listening, Reading, and Performing Skills in College-Level Musicians, Oxford, Oxford University Press.

Kim, Eunjin (2013), "Music Technology-Mediated Teaching and Learning Approach for Music Education. A Case Study from an Elementary School in South Korea," International journal of Music Education, vol. 31, n 4, p. 413-427.

Kosko, Karl, and Richard Ferdig (2016), "Effects of a Tablet-Based Mathematics Application for PreSchool Children," Journal of Computers in Mathematics and Science Teaching, vol. 35, n ${ }^{\circ}$ 1, p. 6179.

Leong, Samuel, and Lee Cheng (2014), "Effects of Real-Time Visual Feedback on Pre-Service Teachers' Singing," Journal of Computer Assisted Learning, vol. 30, nº 3, p. 285-296.

MacIntyre, Peter D., and Gillian K. Potter (2014), "Music Motivation and the Effect of Writing Music. A Comparison of Pianists and Guitarists," Psychology of Music, vol. 42, n 3, p. 403-419.

Maich, Kimberly, and Carmen Hall (2016), "Implementing iPads in the Inclusive Classroom Setting," Intervention in School and Clinic, vol. 5, no 3, p. 145-150.

Mishra, Jennifer (2014), "Improving Sightreading Accuracy. A Meta-Analysis," Psychology of Music, vol. 42, $\mathrm{n}^{\circ}$ 2, p. 131-156, http://journals.sagepub.com/doi/pdf/10.1177/0305735612463770, accessed August 18, 2016.

Paney, Andrew S. (2015), "Singing Video Games May Help Improve Pitch-Matching Accuracy," Music Education Research, vol. 17, n 1, p. 48-56.

Paney, Andrew S., and Ann C. Kay (2015), "Developing Singing in Third-Grade Music Classrooms the Effect of a Concurrent-Feedback Computer Game on Pitch-Matching Skills," Update. Applications of Research in Music Education, vol. 34, n ${ }^{\circ}$ 1, p. 42-49.

Paule-Ruiz, María del Puerto, et al. (2016), "Music Learning in Preschool with Mobile Devices," Behaviour and Information Technology, http://www.tandfonline.com.acces.bibl.ulaval.ca/doi/abs/1 0.1080/0144929X.2016.1198421, accessed August 20, 2016.

Peppler, Kylie, Downton, Michael, and Kenneth Hay (2011), "The Nirvana Effect. Tapping Video Games to Mediate Music Learning and Interest," International Journal of Learning and Media, vol. 3, $\mathrm{n}^{\circ} 1$, p. $41-59$. 
Peters, G. David (1993), "Computer-Based Music Skills Assessment Project. A Portal to Artistic Innovation," Bulletin of the Council for Research in Music Education, n 117, p. 38-45.

Petty, Colleen, and Michele L. Henry (2014), "The Effects of Technology on the Sight-Reading Achievement of Beginning Choir Students," Texas Music Education Research, vol. 23, p. 23-28.

Powell, Josh (2013), "Melodic Dictation. An Examination of Strategy and Time Usage by College Music Students," Master Thesis, Southern Methodist University.

Rogers, Melissa (2013), "Aural Dictation Affects High Achievement in Sight Singing, Performance and Composition Skills," Australian Journal of Music Education, n 1, p. 34-52.

Rowe, Victoria, Triantafyllaki, Angeliki, and Xristina Anagnostopoulou (2015), "Young Pianists Exploring Improvisation Using Interactive Music Technology," International Journal of Music Education, vol. 33, n 1, p. 113-130.

Seddon, Frederick A., and Susan A. O'Neill (2003), "Creative Thinking Processes in Adolescent Computer-Based Composition. An Analysis of Strategies Adopted and the Influence of Instrumental Music Training," Music Education Research, vol. 5, n 2, p. 125-137.

Shibazaki, Kagari, and Nigel A. Marshall (2013), "Gender Differences in Computer- and InstrumentalBased Musical Composition," Educational Research, vol. 55, n 4, p. 347-360.

Silveira, Jason M., and Russell Gavin (2016), "The Effect of Audio Recording and Playback on SelfAssessment Among Middle School Instrumental Music Students," Psychology of Music, vol. 44, $\mathrm{n}^{\circ} 4$, p. $880-892$.

Stowell, Dan, and Simon Dixon (2014), "Integration of Informal Music Technologies in Secondary School Music Lessons," British Journal of Music Education, vol. 31, n 1, p. 19-39.

Upitis, Rena, et al. (2016), "Characteristics of Independent Music Teachers," Music Education Research, http://www.tandfonline.com/doi/abs/10.1080/14613808.2016.1204277?journalCode=cmue20, accessed August 20, 2016.

Uszler, Marienne (1996), “The Independent Music Teacher. Practice and Preparation, Arts Education Policy Review, vol. 97, n 3, p. 20-29.

Ward, Christopher J. (2009), "Musical Exploration Using ICт in the Middle and Secondary School Classroom," International Journal of Music Education, vol. 27, n 2, p. 154-168.

Welch, Graham, David M. Howard, and Christine Rush (1989), "Real-Time Visual Feedback in the Development of Vocal Pitch Accuracy in Singing," Psychology of Music, vol. 17, no 2, p. 146157, http://journals.sagepub.com/doi/pdf/10.1177/0305735689172005, accessed August 18, 2016.

Welch, Graham, et al. (2005), "Real-Time Feedback in the Singing Studio. An Innovatory ActionResearch Project Using New Voice Technology," Music Education Research, vol. 7, n 2, p. 225249. 